\title{
高令者における大腿骨頸部骨折術後の予後調査
}

\author{
肝属郡医師会立病院整形外科 \\ 川越 勝 秀・鈴 木 悠 史 \\ 内 野潔
}

\section{The Recuperation Research of the Patients Operated for Femoral Neck Fracture}

by

\author{
Katsuhide Kawagoe, Yuji Suzuki and Kiyoshi Uchino \\ Kimotsuki Ishikairitu Hospital \\ Takashi Sakou \\ Department of Orthopaedic Surgery, \\ Faculty of Medicine, Kagoshima University
}

\begin{abstract}
We have operated 56 patients over the age of 70 years old for femoral neck fracture since March of 1981 .

The patients who were impossible to walk at this research were $9(16 \%)$, and the major causes were dementia, insufficient rehabilitation and serious osteoarthritis of the knee joint. These causes are very important factors that affect the recuperation of the patients operated.

In this report, we had the following conclusion:

1) To operate as positively and soon as possible is desirable to prevent appearance and progress of dementia.

2) Sufficient rehabilitation is necessary for aged patients operated. But it is difficult without cooperation and understanding of their family.

3) If the patient has serious osteoarthritis that makes him impossible to walk, we must treat it positively.
\end{abstract}

\section{はじめに}

高令者の代表的な骨折の 1 つに大腿骨頸部骨折があ げられる，この骨折は長期臥床した場合, 重篤な合併 症を生じることがよく知られており，早期離床を行う ために積極的に手術することを原則としている。しか し高令者がこのような大きな骨折および手術の侵襲を 受けた後の予後についてはあまり知られていない。今 回われわれは, 当院で手術した 70 才以上の頸部骨折患 者の予後調查を行ったので文献的考察を加えて報告す る.

\section{対象および方法}

昭和 56 年 3 月当院開設以来, 大腿骨頸部骨折に対す る手術は, 71 例 72 関節であった。これらのうち, 70 才 以上の症例は男性 10 例女性 46 例合計 56 例である. 手 術時年令は 70 才から 93 才で, 平均 80 才であり, 術後 調查期間は 4 力月加 4 年 10 力月, 平均 2 年 10 力月 であった。

骨折型は内側型 17 例 (30\%), 外側型 39 例 (70\%) であった。内側骨折を Garden 分類でみると, stage II と stage IVがそれぞれ 6 例 (35\%)，8例 (47\%) と多 
かった。外側骨折を Evans 分類でみると Type I, II といった安定型が 25 例 (64\%), Type I の group III, IV, Type II といった不安定型が 14 例 (36\%) で安定 型が多かった。平均年令は内側型 79 才; 外側型 81 才 で，両型とも 80〜84才でピークをみている.

治療は基本的には内側型に対して人工骨頭置換術を, 外側型に対して Ender 釘, dynamic hip screw (DHS) などを用いた骨接合術を施行した。内側型 17 例のうち 全身状態の悪かった 2 例には海綿骨螺子を，腎部に水 泡を形成した 1 例にはDHSを用いた。残りの 14 例に は人工骨頭置換術を施行した。外側型 39 例に対する骨 接合術は, Ender 釘を用いたものが 18 例ともっとも多 く, DHS 8 例, Jewett 7 例, 他 4 例であった.

全症例の平均手術時間は 1 時間 40 分, 平均麻酔時間 は 2 時間 18 分であり, 麻醉法は硬膜外麻酔がもっとも 多く 29 例 $(52 \%)$ で, 全麻 16 例, 局麻 11 例であった. 腰椎麻醉は 1 例もなかった。

歩行訓練開始までの期間は, 年令では 80 才代が, 骨 折型では内側型が，手術法では人工骨頭を用いたもの が期間が短かかった。 入院日数は, 歩行訓練開始まで の期間に，ほほ比例している（表 1 ).

対象が 70 才以上の高令者であり，56 例中 48 例 (86 ％）に種々の術前合併症がみられた。骨・関節疾患が もつとも多く 19 例, 高血圧 15 例, 心疾患 11 例, 肝. 胆道系疾患 7 例，老人性痴呆 7 例などであった。

\section{結果}

対象 55 名のうち, 生存 39 名 (70\%), 死亡 12 名 (22 $\%$ ，消息不明 4 名（8\%）であった，不明を除いた 51 名のうち, 直接診察し得たのは 26 名で残りの 25 名は, 電話にて調査した。

\section{1. 死亡者 12 名について}

死亡は術後 1 力月から 3 年 10 力月, 平均 1 年 10 力 月の間に起こっている. 死因でもっとも多かったのは 老衰で 5 名 $(42 \%)$ であった。入院中の死亡例は, 老 衰による 1 例のみであった(表 2 )。死亡者の手術時平 均年令は 82 才で, 全体平均上り 2 才高い.また, 種々 の合併症に対しては, 麻酔科および関係各科と充分相 談の上で，術前から術中，術後まで徹底した管理を行 つた。これらのことを総合して考えると，手術および 麻酔による侵襲が死亡の要因になったとは考えにくい，

2. 歩行不能例について

生存者 39 名のうち, 歩行不能であったものは 13 例
表 1 歩行訓練開始までの期間および入院日数

\begin{tabular}{|c|c|c|c|}
\hline & 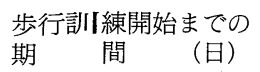 & 入院日数 \\
\hline \multirow{2}{*}{$\begin{array}{l}\text { 年 } \\
\text { 令 }\end{array}$} & 70 才代 & 41 & 98 \\
\hline & 80 才代 & 34 & 92 \\
\hline \multirow{2}{*}{$\begin{array}{l}\text { 骨 } \\
\text { 梊 } \\
\text { 型 }\end{array}$} & 内 側 型 & 29 & 65 \\
\hline & 外 側 型 & 41 & 109 \\
\hline \multirow[b]{2}{*}{ 手 } & 人工骨頭 & 16 & 54 \\
\hline & Ender & 46 & 109 \\
\hline \multirow{2}{*}{ 術 } & Jewett & 24 & 99 \\
\hline & DHS & 32 & 75 \\
\hline \multirow{2}{*}{ 法 } & $\begin{array}{c}\text { multiple } \\
\text { pinning }\end{array}$ & 79 & 262 \\
\hline & 海綿骨螺子 & 64 & 102 \\
\hline \multicolumn{2}{|c|}{ 平 } & 37日 & 94日 \\
\hline
\end{tabular}

表 2 死亡者12名について

\begin{tabular}{|c|c|c|c|c|}
\hline 性 & 死因 & 術式 & 麻酔 & 術前合併症 \\
\hline $1 \mathrm{~K} . \mathrm{K}$. 우 83 & 肺 炎 & 人工骨頭 & 全 & \begin{tabular}{|l} 
冠不全 \\
高血圧
\end{tabular} \\
\hline $2 \mathrm{~T} . \mathrm{H}$. 우 73 & 肺 癌 & 海綿骨螺子 & 局 & $\begin{array}{l}\text { 気管支炎 } \\
\text { 結核 } \\
\end{array}$ \\
\hline $3 \mathrm{H} . \mathrm{I}$. 우 83 & 老 衰 & Ender & 全 & 冠不全 \\
\hline $4 \mathrm{M} . \mathrm{Y}$. 우 82 & 老 衰 & 人工䁌頭 & 全 & 糖尿病 \\
\hline $5 \mathrm{~A} . \mathrm{T}$. 우 81 & 気管支 & Ender & 硬 & 喘息 高血圧 \\
\hline $6 \mathrm{~A}$. I. 우 86 & 老 衰 & Ender & 硬 & \begin{tabular}{|l|} 
左心肥大 \\
喘息 \\
\end{tabular} \\
\hline 7 I.M. 우 93 & 老 衰 & Jewett & 硬 & 高血圧 \\
\hline $8 \mathrm{H} . \mathrm{H}$. 우 82 & 糖尿病 & Jewett & 硬 & $\begin{array}{l}\text { 糖尿病 } \\
\text { 右脚ブロック }\end{array}$ \\
\hline $9 \mathrm{Y} . \mathrm{K}$. 우 88 & 子宮癌 & $\begin{array}{l}\text { multiple } \\
\text { pinning }\end{array}$ & 局 & $\begin{array}{l}\text { 硬化性心疾 } \\
\text { 老人性痴呆 }\end{array}$ \\
\hline $10 \mathrm{~T} . \mathrm{S}$. 우 74 & 窒息死 & DHS & 硬 & 肺癌 \\
\hline $11 \mathrm{~F} . \mathrm{K}$. 우 80 & 老 衰 & DHS & 局 & $\begin{array}{l}\text { 冠不全 } \\
\text { 脳動脈硬化症 }\end{array}$ \\
\hline 12 I. H. व 83 & \begin{tabular}{|l|} 
多発性 \\
骨髄腫
\end{tabular} & 人工骨頭 & 硬 & 多発性骨䯣腫 \\
\hline
\end{tabular}

(23\%)であった。この 13 例の中には，受傷以前より すでに歩行不能であったもの（例えば入院中に車椅子 からベッドへ移る際に転倒し受傷した例)が 4 例あり， 術後に歩行不能となったのは 9 例（16％）であった。 
表 3 術後歩行不能となった例

\begin{tabular}{|c|c|c|c|c|c|c|c|}
\hline & \multicolumn{2}{|c|}{ 年令・性別 } & 骨折型 & 手 術 法 & 退院時 & 調査時 & 因 \\
\hline 1 & 84 & 우 & 外側 & DHS & 可 & 不可 & 高度の両膝関節痛 \\
\hline 2 & 74 & 우 & 内側 & 人工骨頭 & 可 & 不可 & 脳卒中 \\
\hline 3 & 83 & $\sigma^{7}$ & 外側 & Ender & 可 & 不可 & dementia \\
\hline 4 & 76 & 우 & 外側 & DHS & 伝い歩き & 不可 & dementia \\
\hline 5 & 86 & 우 & 外側 & Ender & 寝たきり & 不可 & リハビリ中断（実族が近医へ転院を希望） \\
\hline 6 & 78 & 우 & 外側 & Ender & 車椅子 & 不可 & リハビリ中断（家族が入園を希望） \\
\hline 7 & 93 & ㅇ & 外側 & multiple pinning & 起座 & 不可 & 全身状態 (心疾)が悪化した為, 家族が引き取りを希望 \\
\hline 8 & 80 & $0^{7}$ & 外側 & Ender & 伝い歩き & 不可 & dementia \\
\hline 9 & 76 & 우 & 外側 & Jewett & 車椅子 & 不可 & dementia \\
\hline
\end{tabular}

歩行不能の原因となった合併症として, 老人性痴呆に よるものが 4 例と多く，他は転院によるリハビリの中 断によるものが 2 例, 高度の変形性膝関節症によるも のが 1 例, 心疾患の悪化によるものが 1 例であった. 老人性痴呆の 4 例のうち, 術後に痴呆が出現したもの は 1 例で, 他の 3 例は術前より認められた痴呆が進行 したものであった（表 3 ).

\section{考察}

高令者の大腿骨頸部骨折の治療の重要性は早期離床 歩行, 種々の合併症の克服にある. 1949 年 $E^{2}$ ans ${ }^{1)}$ が, 保存的治療後と観血的治療後の死亡率を比較し, 後者 の優秀性を報告して以来観血的治療が推奨されており, 本骨折の高令者では，受傷後経時的に全身状態が不良 となりやすいので, 観血的治療を早期に実施し, 離床 歩行を可能ならしめることの重要性が広く認められて きている(26)778).

手術では種々ある固定法の選択に関して，いろいろ な論議がなされてきている.内側骨折では, 骨接合術 と人工骨頭置換術の選択, 外側骨折では, 内固定金属 の種類の選択が議論の対象となっている，選択は，そ れぞれの術式の長所短所と, 骨折の型, 患者の状態, 医療設備などの条件との組合せで決まるわけであるか ら一概には言えないが，われわれは，高令者の内側骨 折に対しては, 原則として人工骨頭置換術を, 外側骨 折に対しては，Ender 釘あるいはDHS を多用してい $3^{3) 5}$.

今回の予後調査で, 本骨折とは直接関係のない原因
での死亡例 12 例 (22\%), 術後に歩行不能となった症 例 9 例（16\%）と予後不良のものが多い. 高令者の場 合には，種々の合併症を有している場合が多く，その 中でも予後を大きく左右するものとして，老人性精神 障害は多くの論文で取り上げられてきている21314). 著者 らの症例でも老人性痴呆が骨折前よりすでに存在した ものは骨折後進行し，少数ではあるが骨折後出現して おり，術後のリハビリテイションの実施に困難を来し た，老人性痴呆の発生，進行予防には早期手術による 早期リハビリテーション開始に向かって努力すること が大切であると痛感した。

\section{参 考 文 献}

1) Evans, E. M. : JBJS, 31-B : 190-203, 1949.

2）福地正行・他：老人の骨折とその問題点. 整・災害 外, $12: 1827-1831,1983$.

3）三波三千男 - 他：大腿骨頸部骨折。整-災外，29： 1067-1075, 1986.

4）門馬 満・他：大腿骨頸部骨折の治療よりみた老人 整形外科の問題点. 整・災外， $12 ： 1833-1841 ， 1983$.

5) Richard, S. Laskin: Intratrochanteric Fracture of the Hip in the Elderly. Clin. Orthop., 141: 188195, 1979

6）須藤容章・他：老人の大脚骨頸部骨折に対する手術 適応一全身状態からの考察. 臨整外, $17: 671-678$, 1982.

7）谷口良康・他：高令者の大腿骨頸部骨折治療の検討。 整・災外, 27-32:31, 1981.

8）安田金蔵・他：老人の四肢の骨折の特徵とその治療 法について。整・災外，12:1817-1826，1983. 